\title{
Pendekatan bermain untuk meningkatkan kemampuan passing bawah permainan bola voli
}

\author{
Primadi Pamungkas \\ SMP Muhammadiyah 2 Depok. Jl. Turi 1 Jl. Gempol Raya No.6, Condongcatur, Depok, Kabupaten Sleman, Daerah Istimewa Yogyakarta 55283, Indonesia \\ primadi.pamungkas@gmail.com \\ * corresponding author
}

ARTICLE INFO

Keywords

keterampilan

passing bawah bola voli

pendekatan bermain

\begin{abstract}
Penelitian ini bertujuan meningkatkan kemampuan passing bawah permainan bola voli. Penelitian ini adalah Penelitian Tindakan Kelas (PTK) yang dilaksanakan dalam dua siklus. Siklus I dilakukan sebanyak dua kali pertemuan dan siklus II satu kali pertemuan. Subjek adalah siswa kelas VIII C di SMP Muhammadiyah 2 Depok yang berjumlah 31 siswa terdiri dari 17 siswa laki-laki dan 14 siswa perempuan. Instrumen yang digunakan untuk pengumpulan data adalah RPP untuk 2 siklus, lembar observasi guru peneliti, daftar nilai siswa, instrumen penilaian keterampilan pembelajaran siswa, serta dokumentasi proses belajar. Hasil penelitian menunjukkan bahwa melalui pendekatan bermain dapat meningkatkan kemampuan passing bawah permainan bola voli pada siswa kelas VIII C SMP Muhammadiyah 2 Depok tahun ajaran 2016/2017. Pada siklus I nilai rata-rata 50,54 meningkat menjadi 66,13 pada siklus II. Hasil proses pembelajaran dengan model bermain mampu membuat siswa menjadi bersemangat, aktif, dan rasa ingin mencoba kembali apa yang telah dilakukan, siswa yang tadinya merasa takut menerima bola menjadi lebih termotivasi mengikuti latihan passing bawah sehingga rata-rata nilai akhir yang mereka capai meningkat jika dibandingkan dengan nilai sebelum dilakukan tindakan.
\end{abstract}

This is an open access article under the CC-BY-SA license.

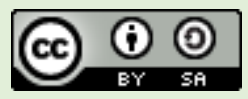

\section{PENDAHULUAN}

Pendidikan jasmani olahraga dan kesehatan (Penjasorkes) memberikan kesempatan pada siswa untuk terlibat langsung dalam aneka pengalaman belajar melalui aktifitas jasmani, bermain dan berolahraga yang dilakukan secara sistematis, terarah, dan terencana. Pembekalan pengalaman belajar itu diarahkan untuk membina sekaligus membentuk gaya hidup sehat dan aktif sepanjang hayat. Penjasorkes adalah proses pendidikan menyeluruh yang menggunakan aktivitas fisik dengan permainan dan olahraga sebagai alatnya.

Ruang lingkup mata pelajaran pendidikan jasmani olahraga dan kesehatan untuk Sekolah Menengah Pertama (SMP) meliputi aspek-aspek sebagai berikut, (1) Permainan dan olahraga, (2) Aktivitas pengembangan, (3) Aktivitas senam, (4) Aktivitas ritmik, (5) Aktivitas air, (6) Pendidikan luar kelas, dan (7) Kesehatan. Dari aspek permainan dan olahraga yang tercantum dalam ruang lingkup pendidikan jasmani terdapat beberapa cabang permainan olahraga yang harus dipelajari oleh siswa salah satunya yaitu permainan bola voli. Usaha yang dapat dilakukan untuk mencapai dan memajukan bola voli adalah dengan memperkenalkan bola voli secara keseluruhan, teknik permainan harus dikuasai dan dipahami, sebab bila melakukan kesalahan bisa berakibat fatal. 
Menurut (Sarumpaet et al., 1992, p. 86) berpendapat, prinsip bermain bola voli adalah memainkan bola dengan memvoli (memukul dengan tangan) dan berusaha menjatuhkannya ke dalam permainan lapangan lawan dengan menyeberangkan bola lewat atas net atau jaring, dan mempertahankannya agar bola tidak jatuh di lapangan sendiri. Permainan bola voli harus dilakukan dengan dipantulkan. Syarat pantulan bola harus sempurna tidak bertentangan dengan peraturan yang berlaku. masing-masing tim dapat memantulkan bola sebanyak-banyaknya tiga kali dan setelah itu bola harus diseberangkan melewati net ke daerah permainan lawan. Untuk memantulkan bola dapat menggunakan seluruh tubuh. Sekarang seluruh bagian tubuh diperkenankan untuk memainkan bola.

Syarat utama agar dapat bermain bola voli adalah menguasai teknik dasar bermain bola voli. Hal ini sesuai pendapat (Sarumpaet et al., 1992) bahwa, agar permainan bola voli berjalan atau berlangsung dengan baik, lancar dan teratur, maka para pemain dituntut harus menguasai unsur-unsur dasar permainan, yaitu teknik dasar bermain bola voli. Teknik dasar bola voli pada dasarnya merupakan suatu upaya seorang pemain untuk memainkan bola berdasarkan peraturan dalam permainan bola voli.

Berkaitan dengan teknik dasar bola voli, Syarifuddin dan Muhadi (1997) menyatakan teknik dasar permainan bola voli merupakan permainan untuk melakukan bentuk-bentuk gerakan yang berhubungan dengan permainan bola voli. Yunus (1992) menyatakan bahwa, teknik dalam permainan bola voli dapat diartikan sebagai cara memainkan bola dengan efektif dan efisien sesuai dengan peraturan permainan yang berlaku untuk mencapai hasil yang optimal. Sedangkan Beutelstahl (2005) berpendapat, teknik merupakan prosedur yang telah dikembangkan berdasarkan praktek, dan bertujuan mencari penyelesaian suatu problem pergerakan tertentu dengan cara yang paling ekonomis dan berguna.

Berdasarkan pengetahuan teknik dasar bola voli yang dikemukakan ahli tersebut dapat disimpulkan bahwa teknik dasar bola voli merupakan suatu gerakan yang dilakukan secara efektif dan efisien. Untuk menyelesaikan tugas yang pasti dalam permainan bola voli. Teknik dalam permainan bola voli merupakan aktivitas jasmani yang menyangkut cara memainkan bola dengan efektif dan efisien sesuai peraturan permainan yang berlaku untuk mencapai suatu hasil yang optimal.

Adapun macam-macam teknik dasar bola voli menurut Sarumpaet et al. (1992) yaitu passing atas, passing bawah, set-up, bermacam-macam servis, bermacam-macam smash (spike), bermacammacam block (bendungan). Sedangkan teknik dasar bermain bola voli menurut Suharno (1981) dibedakan menjadi dua, yaitu teknik tanpa bola dan teknik dengan bola. Secara garis besar teknik dasar bermain bola voli terdiri atas teknik tanpa bola dan teknik dengan bola. Teknik tanpa bola merupakan gerakan-gerakan khusus yang mendukung penguasaan teknik dengan bola. Sedangkan teknik dengan bola merupakan cara-cara memainkan bola dalam permainan bola voli. Kedua teknik tersebut saling berkaitan dan tidak dapat dipisahkan dalam pelaksanaan bermain bola voli. Keterkaitan antara teknik tanpa bola dan teknik dengan bola didasarkan pada kebutuhan dalam permaianan.

Dalam permainan bola voli, hal yang paling dasar adalah teknik passing bawah, karena tanpa teknik passing bawah permainan akan mudah berhenti dan tidak adanya kesempatan untuk melakukan serangan atau smash, meskipun smash adalah langkah untuk mencetak skor dan sekaligus untuk memenangkan pertandingan. Teknik adalah suatu proses melahirkan keaktifan jasmani dan pembuktian dalam praktek dengan sebaik mungkin untuk menyelesaikan tugas yang pasti dalam cabang permainan bola voli (D. I. M. Saputra \& Gusniar, 2019). Pendapat senada dikemukakan juga oleh (Yunus, 1992) yang mengatakan bahwa teknik adalah cara melakukan sesuatu untuk mencapai tujuan tertentu secara efektif dan efisien.

Syarifuddin dan Muhadi (1997) mengatakan, pass (passing) bawah adalah mengambil bola yang berada dibawah badan atau bola dari bawah dan biasanya dilakukan dengan kedua lengan bagian bawah (dari siku sampai pergelangan tangan yang dirapatkan), baik untuk dioperasikan kepada kawan, maupun langsung ke lapangan lawan melalui di atas jaring. Ahmadi (2007) mengatakan bahwa kegunaan passing bawah antara lain: untuk menerima bola servis, untuk penerimaan bola dari lawan yang berupa serangan/smash, untuk pengambilan bola setelah terjadi block atau bola dari pantulan net, ntuk menyelamatkan bola yang kadang-kadang terpental jauh diluar lapangan permainan, untuk pengambilan bola yang rendah dan mendadak datangnya. 
Bermain merupakan bagian hidup dari kehidupan manusia, khususnya bagi anak-anak bermain tidak dapat dipisahkan dari mereka. Menurut (Y. M. Saputra, 2001) bermain adalah suatu kegiatan yang menyenangkan. Bermain yang dilakukan secara tertata, mempunyai manfaat yang besar bagi perkembangan siswa. Pendekatan bermain efektif karena dapat meningkatkan kemampuan kognitif, memenuhi perasaan ingin tahu, kemampuan inivatif, kritis, dan kreatif, juga membantu mengatasi perasaan bimbang dan tertekan. Dengan merancang pelajaran tertentu untuk dilakukan sambil bermain, anak belajar sesuai tuntutan taraf perkembangannya.

Bermain merupakan salah satu bentuk kegiatan dalam pendidikan jasmani. Oleh karena itu bermain dalam usaha pendidikan mempunyai tugas dan tujuan sama dengan tugas dan tujuan pendidikan jasmani. Menurut Matakupan (1995) peranan bermain dalam penumbuhan tugas pendidikan jasmani ialah: Bermain bagi anak adalah hidup dan kehidupan, Bermain bagi anak adalah menemui diri, Bermain bagi anak adalah penemuan lingkungan, Bermain bagi anak adalah kebebasan, Bermain bagi anak adalah kegembiraan, Bermain bagi anak adalah hubungan atau interaksi dengan orang lain, Bermain bagi anak adalah keunggulan, Bermain bagi anak adalah ritmik, Bermain bagi anak adalah anggun, dan Bermain bagi anak adalah belajar.

Dengan mengetahui manfaat bermain diharapkan guru dapat mengembangkan aspek perkembangan siswa. Menurut Y. M. Saputra (2001) aspek dalam pendekatan bermain meliputi perkembangan fisik, perkembangan motorik, perkembangan sosial, perkembangan emosional, perkembangan keterampilan olahraga. Berdasarkan penjelasan tersebut dapat disimpulkan bahwa pendekatan bermain adalah salah satu bentuk dari sebuah pembelajaran jasmani yang dapat diberikan disegala jenjang pendidikan untuk suatu kegiatan yang menyenangkan, selain itu dengan mengetahui manfaat bermain diharapkan guru dapat melahirkan ide mengenai cara memanfaatkan kegiatan bermain untuk mengembangkan bermacam-macam aspek perkembangan siswa pada passing bawah. Pendekatan bermain tersebut dapat diterapkan dalam proses pembelajaran passing bawah yaitu dengan memberikan bentuk bermain terlebih dahulu sebelum evaluasi.

Dalam proses pembelajaran bola voli di SMP Muhammadiyah 2 depok terdapat beberapa permasalahan, keterbatasan sarana pendukung, alokasi waktu yang dibutuhkan untuk ketercapaian kompetensi dasar. selain keterbatasan sarana pembelajaran bola voli, guru juga dihadapkan dengan alokasi waktu/jam pelajaran yang terbatas. Jam pelajaran yang terbatas kurang mencukupi dalam penyampaian pembelajaran permainan bola voli secara maksimal. Dengan alokasi 2 kali pertemuan untuk materi permainan bola voli. Pada proses kegiatan belajar mengajar pendidikan jasmani, khususnya bola voli, siswa masih kesulitan dalam melakukan gerakan passing bawah. Berdasarkan pengamatan pada saat melakukan proses pembelajaran, masih banyak siswa yang belum bisa melakukan passing bawah. Hal itu ditunjukkan saat siswa melakukan latihan passing, siswa sering melakukan kesalahan dalam melakukan teknik dasar passing bawah bola voli terutama pada impact bola, hal ini dikarenakan perkenaan bola tidak tepat sehingga passing bawah menjadi tidak baik, serta siswa merasa tangannya sakit ketika melakukan passing bawah, bola yang di passing telempar jauh dan tidak mengarah kepada sasaran yang dituju. Hal ini terjadi karena siswa masih belum bisa menguasai teknik dasar tersebut.

Kurang efektif pada pembelajaran passing bawah dalam permainan bola voli perlu adanya pemecahan masalah agar pembelajaran bola voli dapat dilaksanakan sesuai dengan tujuan pembelajaran. Guru yang kreatif akan mampu menciptakan suatu model pembelajaran baru, dapat disajikan dengan cara yang lebih menarik, sehingga anak akan merasa lebih senang, dan lengan tidak merasakan sakit lagi saat pengambilan bola passing bawah. Model pembelajaran berbasis masalah misalnya, membantu siswa dalam memecahkan masalah, termasuk dalam pelajaran olahraga (Adolphus, 2011; Konstantaki, 2015; Prabandaru et al., 2020). Dari hasil pengalaman mengajar maka guru melakukan pembelajaran dengan menggunakan pendekatan model bermain. Bermain merupakan bagian hidup dari kehidupan manusia, khususnya bagi anak-anak bermain tidak dapat dipisahkan dari mereka. Menurut Y. M. Saputra (2001) bermain adalah suatu kegiatan yang menyenangkan. Bermain yang dilakukan secara tertata, mempunyai manfaat yang besar bagi perkembangan siswa. Pendekatan bermain efektif karena dapat meningkatkan kemampuan kognitif, memenuhi perasaan ingin tahu, kemampuan inivatif, kritis, dan kreatif, juga membantu mengatasi perasaan bimbang dan tertekan. 


\section{METODE}

Penelitian ini merupakan Penelitian Tindakan Kelas (PTK) yang dilakukan di SMP Muhammadiyah 2 Depok. Pada dasarnya terdapat 4 tahapan dari penelitian tindakan kelas yaitu perencanaan, tindakan, observasi dan refleksi (Arikunto et al., 2010). Penelitian ini akan mengaplikasikan pembelajaran dengan pokok permasalahan bagaimana cara meningkatkan pembelajaran penguasaan teknik dasar passing bawah dengan menggunakan pendekatan bermain pada siswa kelas VIII C SMP Muhammadiyah 2 Depok. PTK ini dilaksanakan dalam 2 siklus untuk mengetahui peningkatan kemampuan passing bawah permainan bola voli siswa dengan menggunakan pendekatan bermain. Dalam setiap siklusnya dilakukan tahap-tahap perencanaan, tindakan, pengamatan, dan refleksi. Perencanaan sebagai tahap awal dilakukan untuk merencanakan skenario pembelajaran dan juga menyiapkan fasilitas pendukung untuk melaksanakan skenario tersebut. Tindakan atau pelaksanaan merupakan penerapan dari skenario yang telah dibuat. Pada tahap ini guru melaksanakan pembelajaran passing bawah dengan menggunakan pendekatan bermain. Pengamatan merupakan pelaksanaan untuk mengetahui dan mendokumentasikan hal-hal yang terjadi selama tindakan berlangsung. Hasil dari pengamatan digunakan sebagai dasar untuk refleksi. Refleksi dilakukan untuk menganalisis hasil pengamatan dan untuk menentukan tindakan apa yang akan dilakukan selanjutnya.

Subjek dalam penelitian ini adalah siswa kelas VIII C yang berjumlah 31 siswa terdiri dari 17 siswa laki-laki dan 14 siswa perempuan di SMP Muhammadiyah 2 Depok tahun pelajaran 2016/2017. Data dalam penelitian ini dikumpulkan melalui proses pengamatan (data lembar observasi) digunakan untuk menilai proses pembelajaran yang dilakukan oleh guru, hasil tes siswa (tes unjuk kerja) digunakan untuk menilai hasil belajar siswa dalam melakukan passing bawah digunakan untuk menilai proses pembelajaran dari siswa. Data yang dikumpulkan pada setiap kegiatan dianalisis secara kualitatif dan kuantitatif. Dimana analisis data secara kualitatif disajikan dalam bentuk tulisan atau deskripsi berupa kata-kata dalam semua proses penelitian yang dilakukan oleh peneliti mulai dari persiapan hingga akhir. Sedangkan analisis data secara kuantitatif data disajikan dalam bentuk menggunakan persentase (\%) dalam setiap siklusnya. Sehingga data akan disajikan dalam bentuk nilai atau angka.

\section{HASIL DAN PEMBAHASAN}

Penelitian tindakan kelas dilaksanakan dalam 2 siklus dimana setiap siklus dilaksanakan dalam 2 kali pertemuan. Hasil penelitian dijabarkan sebagai berikut:

\section{Siklus I}

Tahap perencanaan diawali dengan menyusun perangkat pembelajaran yaitu dengan membuat Rencana Pelaksanaan Pembelajaran (RPP), lembar observasi, membuat instrument tes penilaian passing bawah, dan menyiapkan sarana dan prasarana yang akan digunakan dalam proses pembelajaran. Pelaksanaan tindakan kelas pada proses pembelajaran dalam siklus I berlangsung 2 kali pertemuan, pertemuan pertama dilakukan pada tanggal 12 Oktober 2016 selama 2 jam pelajaran (2x40 menit), dan pertemuan kedua pada tanggal 19 Oktober 2016. Tahapan pelaksanaan PTK ini di awali dengan kegiatan pendahuluan, guru memberikan salam kemudian melakukan apersepsi. Setelah itu guru memberikan penjelasan tentang rencana kegiatan yang akan dilakukan dan memberikan tugas kepada siswa untuk melakukan pemanasan. Tindakan pada pertemuan pertama guru menggunakan beberapa permainan dalam proses pembelajaran, yang pertama adalah permainan bola botol. Siswa dibagi menjadi 2 kelompok yang sama banyak. Setiap anggota kelompok bergantian membawa bola dari belakang mendekati net dengan membawa bola di atas lengan tangan antara pergelangan tangan sampai siku, kemudian melemparkan bola seperti passing melewati net dan berusaha tepat sasaran untuk menjatuhkan botol yang berisi air yang ada di daerah sebelah. Setiap 1 botol yang jatuh bernilai 1 point, setiap kelompok berusaha mengumpulkan point sebanyak banyaknya.

Permainan kedua adalah dengan melakukan permainan bola suara angka. Siswa dibagi menjadi 2 kelompok besar, salah satu kelompok akan melakukan permainan dan kelompok yang lain menjaga dan mengambil bola. Siswa berbaris dalam 1 barisan dan salah satu orang berada di depan sebagai pengumpan atau pelempar. Pelempar menyebutkan salah satu dari angka 1-5 agar siswa di dalam barisan melakukan passing bawah melewatkan bola diatas net dan menjatuhkan bola di petak yang sudah bertuliskan angka 1-5 sesuai dengan instruksi pelempar. Siswa setelah sebagai pengumpan 
berlari ke barisan paling belakang agar dilanjutkan siswa berikutnya. Apabila bola jatuh tidak sesuai dengan instruksi pelempar, maka diulangi sekali lagi. Apabila masih gagal pemain berikutnya yang akan mendapat giliran.

Permainan lempar bola passing bawah bola pantul berpasangan dan berkelompok: Siswa dibagi menjadi 4-5 kelompok dengan ketentuan tiap kelompok terdiri dari 5-6 orang. Tiap kelompok dibagi menjadi dua sama banyak dan saling berhadapan. Setelah ada aba-aba, siswa yang memegang bola melambungkan bola kearah teman yang ada di depannya untuk kemudian melakukan passing bawah. Bola harus memantul terlebih dahulu di lantai sebelum di passing. Kegiatan tersebut diulang beberapa kali sampai semua melakukan. Tujuan permainan ini adalah untuk melatih pergerakan lengan dalam penguasaan gerakan passing bawah agar tepat sasaran dan melatih kelincahan siswa untuk melakukan gerak.

Pada pertemuan kedua guru menggunakan satu permainan, yaitu bermain balapan F1. siswa dibagi menjadi dua kelompok sama banyak, siswa berdiri membungkuk dengan posisi lengan lurus dan jari-jari tangan meregang dibelakang bola (bola diletakkan di bawah), berjalan kedepan dengan jarak kira-kira 7 meter sampai batas yang telah ditentukan, kemudian kembali lagi kebarisan. Siswa berikutnya melakukan hal yang sama, namun ketika siswa tersebut belum sampai kebarisan bola tidak boleh di berikan kepada orang yang berikutnya. Saat menggiring bola boleh dengan berjalan cepat ataupun berlari. Tujuan permainan ini adalah untuk melatih dan membiasakan lengan tetap lurus dalam pengenalan teknik passing bawah. Setelah permainan pada pertemuan kedua selesai, kemudian dilanjutkan dengan melakukan tes kemampuan passing bawah selama 1 menit secara bergantian.

Observasi atau pengamatan yang dilakukan observer dengan mencatat dan mendokumentasikan hal-hal yang terjadi selama tindakan berlangsung. Observasi yang dilakukan dengan berpedoman pada lembar observasi. Hasil observasi pengamatan kelas terhadap guru selama proses pembelajaran berlangsung dapat diperoleh gambaran bahwa guru belum melakukan koreksi secara menyeluruh apabila terjadi kesalahan, dan juga belum melakukan kegiatan pendinginan dan penenangan terhadap siswa. Nilai proses pembelajaran yang dilakukan guru sebesar 62 dengan kategori baik. Selama siklus pertama dilakukan siswa banyak mengalami kesulitan dalam melakukan pelaksanaan gerakan, karena masih belum terbiasa pada saat perkenaan bola dengan lengan. Hasil tes kemampuan passing bawah siswa menunjukkan baru 23\% siswa yang lulus, yaitu 7 siswa tuntas dan 24 siswa tidak tuntas, dengan nilai rata-rata 50,54. Hasil belajar passing bawah pada siklus I dapat dilihat pada tabel 1.

Table 1. Data hasil belajar passing bawah siklus I

\begin{tabular}{|c|c|c|c|c|c|c|c|}
\hline \multirow{2}{*}{ No. } & \multirow{2}{*}{ Uraian } & \multicolumn{2}{|c|}{ Siswa yang belum tuntas } & \multicolumn{2}{|c|}{ Siswa yang sudah tuntas } & \multirow{2}{*}{ Jumlah siswa } & \multirow{2}{*}{ Rata-rata nilai } \\
\hline & & $f$ & $\%$ & $f$ & $\%$ & & \\
\hline 1. & Siklus I & 24 & 77 & 7 & 23 & 31 & 50,54 \\
\hline
\end{tabular}

Setelah selesai melakukan tindakan guru dan kolaborator melakukan refleksi melalui analisis terhadap data dari hasil observasi, hasil tes, dan dokumentasi yang ada. Ini bertujuan untuk mengetahui kelebihan dan kekurangan yang terjadi saat proses pembelajaran berlangsung. Berdasarkan data hasil pengamatan terhadap pelaksanaan proses pembelajaran pada siklus ini, bahwa sebagian besar siswa masih mengalami kesulitan dalam melakukan pelaksanaan gerakan, karena masih belum terbiasa pada saat perkenaan bola dengan lengan menjadikan siswa masih merasa takut dan tegang. Kemampuan siswa yang berbeda dalam penguasaan passing bawah dalam bermain bola voli menjadi salah satu kendala dalam mencapai keberhasilan untuk meningkatkan kemampuan passing bawah. Selama proses berlangsung masih dijumpai siswa yang kurang maksimal dalam melakukan gerakan. Hal ini dipengaruhi oleh ketidakmampuan siswa dalam melakukan gerakan passing bawah dengan benar. Disamping itu dengan keterbatasan sarana dan prasarana yang dimiliki membuat beberapa siswa menjadi bosan dan jenuh dalam menunggu giliran untuk melakukan tes kemampuan passing bawah. Namun, masih ada beberapa siswa yang bersemangat, aktif, dan memiliki rasa ingin mencoba kembali apa yang telah dilakukan. 


\section{Siklus II}

Tahap perencanaan ini kegiatan yang dilakukan adalah membuat skenario pembelajaran dan mempersiapkan sarana dan prasarana yang akan digunakan dalam proses pembelajaran. Pada tahap ini peneliti sudah mendata dan mengidentifikasi, dan menganalisis yang akan dilakukan dalam penelitian tindakan kelas dari hasil refleksi pada siklus I. sebelum memulai pembelajaran pada siklus II guru menugaskan kepada siswa untuk berlatih gerakan passing bawah agar menjadi terbiasa dalam melakukan gerakan.

Pelaksanaan tindakan kelas pada proses pembelajaran dalam siklus II berlangsung 1 kali pertemuan karena keterbatasan waktu yang ada. Pertemuan dilakukan pada tanggal 26 Oktober 2016 selama 2 jam pelajaran (2x40 Menit). Tahapan pelaksanaan tindakan ini di awali dengan kegiatan pendahuluan, guru memberikan salam kemudian melakukan apersepsi. Setelah itu guru memberikan penjelasan tentang rencana kegiatan yang akan dilakukan dan memberikan tugas kepada siswa untuk melakukan pemanasan. Pada pertemuan ini peneliti guru menggunakan satu permainan yaitu permainan lempar bola passing bawah. Siswa dibagi menjadi 2 kelompok. Tiap kelompok membentuk satu banjar dan salah satu anggota kelompok berdiri didepan berhadapan dengan kelompoknya. Setelah ada aba-aba, siswa yang memegang bola melambungkan bola ke arah teman yang ada di depannya untuk kemudian melakukan passing bawah. Bola harus dipassingkan kembali kepada orang yang melempar bola. Kegiatan tersebut diulang beberapa kali sampai semua melakukan.

Tujuan pembelajaran ini adalah untuk melatih lengan dalam menerima bola, ketepatan dalam mengoper bola dalam pengenalan teknik passing bawah, serta memberikan rasa senang, percaya diri, dan bersaing dalam penguasaan teknik passing bawah. Setelah melakukan permainan, guru mengajarkan teknik passing bawah kepada siswa dan siswa disuruh melakukan tes evaluasi yaitu dengan melakukan tes passing bawah secara individu. Observasi atau pengamatan yang dilakukan observer dengan mencatat dan mendokumentasikan hal-hal yang terjadi selama tindakan berlangsung. Observasi yang dilakukan dengan berpedoman pada lembar observasi. Hasil observasi pengamatan kelas terhadap guru selama proses pembelajaran berlangsung dapat diperoleh gambaran secara umum bahwa guru sudah melakukan kegiatan pembelajaran sesuai dengan yang direncanakan. Nilai proses pembelajaran yang dilakukan guru pada siklus II sebesar 70 dengan kategori baik.

Selama siklus II dilakukan masih ada beberapa siswa yang mengalami kesulitan, yaitu pada saat pelaksanaan gerakan, karena masih belum terbiasa dengan bola dan perkenaannya dengan tangan. Hasil tes kemampuan passing bawah siswa menunjukkan baru 39\% siswa yang lulus, yaitu 12 siswa tuntas dan 19 siswa tidak tuntas, dengan nilai rata-rata $66,13$.

Table 2. Hasil belajar passing bawah siklus II

\begin{tabular}{cccccccc}
\hline \multirow{2}{*}{ No. } & \multirow{2}{*}{ Uraian } & \multicolumn{2}{c}{ Siswa yang belum tuntas } & \multicolumn{2}{c}{ Siswa yang sudah tuntas } & \multirow{2}{*}{ Jumlah siswa } & Rata-rata nilai \\
\cline { 3 - 6 } & & $f$ & $\%$ & $f$ & $\%$ & & 50,54 \\
\hline 1. & Siklus I & 24 & 77 & 7 & 23 & 31 & 66,13 \\
2. & Siklus II & 19 & 61 & 12 & 39 & 31 & 6 \\
\hline
\end{tabular}

Setelah selesai tindakan sampai akhir siklus peneliti dan kolaborator mendiskusikan hasil pengamatan. Dengan adanya tindakan penelitian ini bisa menambah semangat siswa dalam pembelajaran passing bawah. Demikian juga hasil belajar dari tindakan pada siklus pertama sampai siklus kedua ada peningkatan kemampuan passing bawah. Hasil pengamatan terhadap guru pada siklus II memiliki skor 70 dengan kategori baik, hal ini mengalami peningkatan dari siklus sebelumnya yaitu dengan skor 62. Kemampuan hasil belajarn passing bawah siswa juga mengalami peningkatan nilai rata-rata sebesar 66,13. Hal ini meningkat dari siklus sebelumnya yaitu 50,54. Dalam upaya mencapai kemampuan passing bawah, peneliti menggunakan model pendekatan bermain dengan penekanan posisi dan sikap tubuh dalam melakukan passing bawah. Dimana posisi dan sikap tubuh tersebut merupakan aspek penentu dalam melakukan gerakan passing, diantaranya adalah posisi kaki, posisi badan, posisi tangan, dan arah bola.

Pembelajaran menggunakan model bermain ternyata dapat mempengaruhi proses dan hasil pembelajaran passing bawah. Secara umum siswa mampu lebih baik dalam melakukan keterampilan passing bawah bola voli yang diberikan oleh guru. Hal ini dikarenakan pembelajaran dengan model bermain mampu membuat siswa menjadi bersemangat, aktif, dan rasa ingin mencoba kembali apa yang telah dilakukan, selain itu permainan yang digunakan oleh guru dalam pembelajaran mengarah 
atau mendekati kegiatan seperti melakukan keterampilan passing bawah, sehingga siswa merasa tertantang dan tidak merasa jenuh. Suasana saat pembelajaran berlangsung juga sangat kondusif dan siswa juga merasa senang walau terlihat kelelahan. Dalam pelaksanaannya siswa begitu bersemangat, antusias, dan sedikit kelelahan, namun hal itu tergantikan dengan rasa senang karena model bermain yang diterapkan guna meningkatkan keterampilan passing bawah bola voli.

Hasil belajar siswa secara umum menunjukkan ada peningkatan dalam kemampuan passing bawah. Para siswa yang tadinya merasa takut menerima bola menjadi lebih termotivasi mengikuti latihan passing bawah sehingga rata-rata nilai akhir yang mereka capai meningkat jika dibandingkan dengan nilai sebelum dilakukan tindakan.

\section{SIMPULAN}

Berdasarkan analisis terhadap hasil penelitian yang telah dilakukan, maka diperoleh kesimpulan sebagai berikut; (1) Pendekatan bermain dilaksanakan dengan cara memberikan permainan yang mengarah pada pelaksanaan passing bawah. Permainan dilakukan dengan permainan yang sederhana sehingga memudahkan siswa dalam memahami konsep melakukan passing bawah. Penerapan pendekatan bermain dapat meningkatkan proses dan hasil belajar passing bawah siswa. Hal tersebut bisa dilihat dengan adanya peningkatan rata-rata persentase nilai ketuntasan hasil belajar siswa pada akhir siklus; (2) Model bermain mampu membuat siswa menjadi bersemangat, aktif, dan rasa ingin mencoba kembali apa yang telah dilakukan. Siswa yang tadinya merasa takut menerima bola saat hendak melakukan passing bawah, dengan melalui pendekatan bermain ini menjadi lebih termotivasi untuk mengikuti latihan passing bawah. Sehingga terjadi peningkatan nilai akhir dibandingkan dengan nilai sebelum dilakukannya tindakan

\section{REFERENSI}

Adolphus, T. (2011). Problems of teaching and learning of geometry in secondary schools in Rivers State, Nigeria. International Journal of Emerging Sciences, 1(2), 143-152. https://doi.org/http://hdl.handle.net/1893/26189

Ahmadi, N. (2007). Permainan bola voli. Era Intermedia.

Arikunto, S., Suhardjono, \& Supardi. (2010). Penelitian tindakan kelas. Bumi Aksara.

Beutelstahl, D. (2005). Belajar bermain bola volley. CV. Pionir Jaya.

Konstantaki, M. (2015). Applying Problem based learning in the Sports Science Curriculum. Athens Journal of Sports, 2(1), 7-16. https://doi.org/10.30958/ajspo.2-1-1

Matakupan, J. (1995). Teori bermain: Modul 1-6. Depdikbud.

Prabandaru, R. D., Lismadiana, L., \& Nanda, F. A. (2020). Problem-based learning approach to improve service skills of badminton in physical education learning. International Journal of Education and Learning, 2(1), 14-24. https://doi.org/10.31763/ijele.v2i1.74

Saputra, D. I. M., \& Gusniar, G. (2019). Meningkatkan hasil belajar passing bawah bola voli melalui bermain melempar bola. Gelanggang Olahraga: Jurnal Pendidikan Jasmani Dan Olahraga, 3(1), 64-73.

Saputra, Y. M. (2001). Pembelajaran atletik di sekolah dasar. Depdiknas.

Sarumpaet, A., Djazet, Z., \& Sadikun, I. (1992). Permainan bola besar. Depdikbud.

Suharno, H. P. (1981). Metodik melatih permainan bolavoli. IKIP Yogyakarta.

Syarifuddin, A., \& Muhadi, M. (1997). Pendidikan jasmani dan kesehatan. Grasindo.

Yunus, M. (1992). Olahraga pilihan bola voli. Depdikbud. 